\title{
Early defoliation effects on water status, fruit yield and must quality of 'Nerello
}

\section{mascalese' grapes}

\author{
Filippo Ferlito ${ }^{1}$, Maria Allegra ${ }^{1} \odot$, Biagio Torrisi ${ }^{1} \odot$, Helena Pappalardo ${ }^{1}$, Alessandra Gentile ${ }^{2} \oplus$, Stefano La Malfa ${ }^{2}$, Alberto \\ Continella ${ }^{2} \odot$, Fiorella Stagno ${ }^{1 \odot}$, Elisabetta Nicolosi ${ }^{2 *}{ }^{\odot}$
}

${ }^{1}$ Consiglio per la ricerca in agricoltura e l'analisi dell'economia agraria/Centro di Ricerca Olivicoltura, Frutticoltura e Agrumicoltura, Corso Savoia, 190 - 95024 Acireale, CT - Italy.

2Università degli Studi di Catania - Dipartimento di Agricoltura, Alimentazione e Ambiente, Via Valdisavoia, 5 95123 - Catania - Italy.

*Corresponding author <enicolo@unict.it>

Edited by: Mohammad Valipour

Received January 31, 2019

Accepted May 01, 2019
ABSTRACT: The effect of basal zone defoliation on vines influences yield and ripening depending on the phenological stage and its intensity. Early basal defoliation (EBD) was carried out at flowering on the autochthonous Vitis vinifera (L.) cultivar 'Nerello mascalese' grown on the eastern slopes of Mount Etna, Sicily. The effects were evaluated over a two-year period. In the first year, the canopy retained $67 \%$ of its original leaf area after EBD and in the second year, $58 \%$. Compared with control vines, mid-day leaf water potentials in the EBD vines enjoyed higher water status throughout the growing seasons in both years. EBD had no significant negative effects on yield but did have significant positive effects on the levels of total polyphenols, total flavonols and total anthocyanins. Yield and its components are conditioned by a number of factors mainly linked to climate and to the vines' general condition during berry growth and ripening. Even after two consecutive years of treatment, EBD does not have any negative effects on yield. However, EBD does have strong positive effects on berry quality attributes as a consequence of the following: greater exposure of the cluster to sunlight, higher vine water status and avoidance of high temperature stresses in the last phase of ripening during the analysis of anthocyanin.

Keywords: Vitis vinifera (L.), photosynthesis, canopy, sustainability, berry quality

\section{Introduction}

Nowadays, partial defoliation in the basal zone of the grapevine shoot is a common management practice used to control the microclimate in the cluster area. This practice regulates the shade/exposure balance and the ratio of the older less photosynthetically active leaves to the younger more photosynthetically active leaves (Intrieri et al., 2008). The effects of basal zone defoliation depend on the phenological stage at which it is implemented and on its intensity (Candolfi-Vasconcelos and Koblet, 1990; Poni et al., 2006). Early basal defoliation (EBD), implemented from the pre-flowering to the early fruit set only, can influence both yield (Poni et al., 2006) and ripening (Ferlito et al., 2014). Yield reduction is likely due to a lower fruit set and smaller berries (Nicolosi et al., 2012; Poni et al., 2008) as a consequence of upsetting the source-sink balance. Before veraison, basal defoliation can lower shoot phothosynthesis (Kotseridis et al., 2012). Hunter and Visser (1988) suggested that excess vegetative growth is detrimental to interior-canopy microclimate as well as the photosynthetic rate of the entire vine. However, this effect may not be strong because grapes have great resilience, showing compensatory increases in lateral growth and in the photosynthetic efficiency of younger leaves (Reynolds and Wardle, 1989). Meanwhile, fruit quality parameters are positively affected by EBD and are key to the oenological wine profile as measured by the fruit's biochemical characteristics (Feng et al., 2017; Pisciotta et al., 2013). Increases in bunch exposure are generally associated with increases in the ratio of total soluble solids/titratable acidity (Pastore et al., 2017). The other fruit quality attributes are often more strongly affected by cultivation practices, the environment and the genotype (Ferlito et al., 2014; Downey et al., 2006). Generally, anthocyanin accumulations are positively related to the increased light exposure associated with defoliation (Main and Morris, 2004; Chorti et al., 2010; Pastore et al., 2017) and negatively related to the associated higher berry temperatures. Effects of increased light exposure on berry flavonoids are unclear. Lemut et al. (2013) found that increased light has a positive effect on flavonoid synthesis while others have reported decreased levels of these compounds (Spayd et al., 2002; Tarara et al., 2008; Pisciotta et al., 2013; Scafidi et al., 2018).

The aim of this research was to investigate the effects of EBD as a tool for yield control and fruit quality improvement in the black grape cultivar 'Nerello mascalese' grown on the eastern slopes of Mount Etna.

\section{Materials and Methods}

\section{Site description, plant material and experimental design}

The trial was conducted over two consecutive seasons (2015 and 2016) in a commercial Vitis vinifera (L.) vineyard (lat. $37^{\circ} 41^{\prime} 13^{\prime \prime} \mathrm{N}$; long. $15^{\circ} 07^{\prime} 00^{\prime \prime} \mathrm{E}$; elevation $602 \mathrm{~m}$ a.s.l.) (Figure 1). Vines of the black cultivar 'Nerello mascalese' grafted onto $140 \mathrm{Ru}$. rootstock were planted in 2010 with north-south rows in Zafferana Etnea, Catania, on the eastern slopes of Mount Etna, Italy. Vines were planted at a spacing of $0.9 \mathrm{~m}$ (in row) $\times 2.50 \mathrm{~m}$ (between rows) and trained to a unilateral cordon system at a height of $0.5 \mathrm{~m}$. All vines were spur pruned to three or four spurs per vine and two buds 


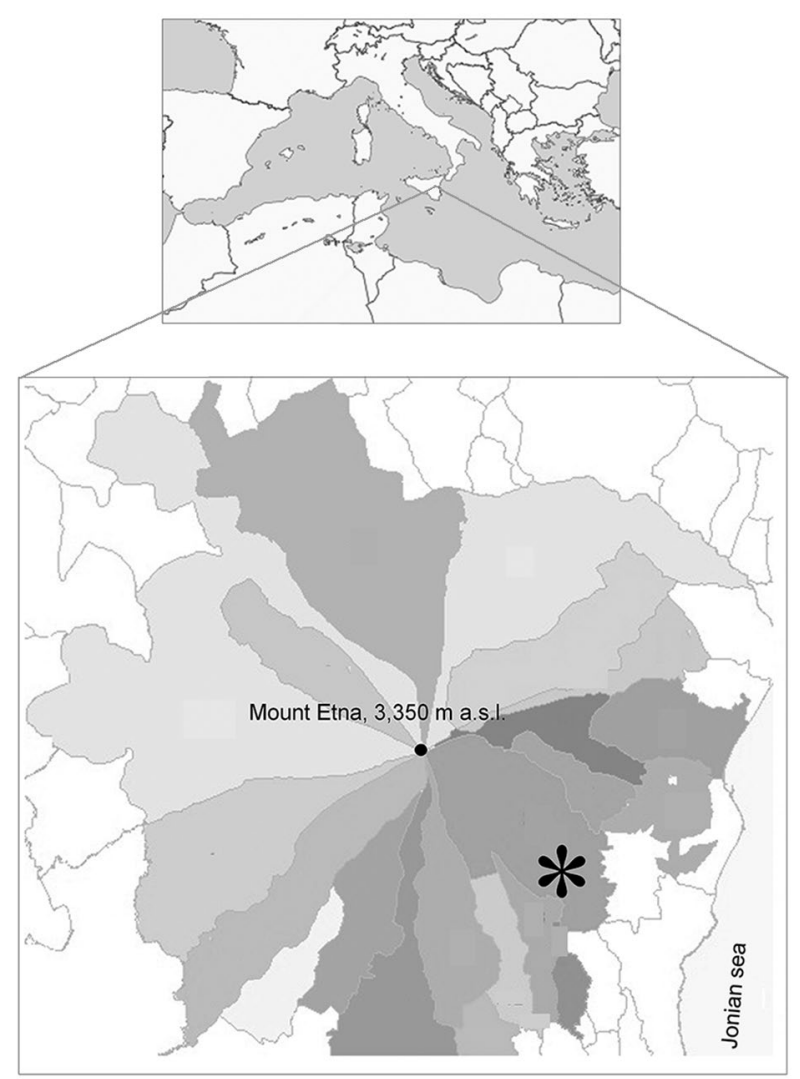

Figure 1 - Map of the study area. "Experimental vineyard (lat. $37^{\circ} 41^{\prime} 13^{\prime \prime} \mathrm{N}$, long. $15^{\circ} 07^{\prime} 00^{\prime \prime} \mathrm{E}$, elevation $602 \mathrm{~m}$ a.s.l.) and

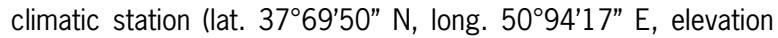
$591 \mathrm{~m}$ a.s.l.); Frequence of the relevament: 180', acquisition system: micros M93) in the Zafferana Etnea district (Catania, Sicily).

per spur. All vines were later standardised by removing by hand all shoots derived from the bourillon (first small bud), the crown and any adventitious buds so as to retain six-eight shoots per vine. The shoots were positioned vertically, aligned in the row direction and were not hedged during the growing season. The vineyard was not irrigated and soil tillage was mechanical. The trial was a completely randomised design with three independent plots of five rows, each containing 20 vines. All measurements were taken from three 'index' vines per block.

\section{Climate and soil}

Daily temperature and rainfall data and long-term climatic data of the site were provided by the Sicilian Water Observatory (www.osservatorioacque.it). The climate of the trial site is characterised by wet winters and semi-arid summers (Figures 2A, B and C). In the previous 30 years, according to the June-Aug rainfall, 14 seasons were characterized as dry (0-50 mm of rain), 9 seasons as normal (50-100 $\mathrm{mm}$ of rain) and 7 as wet

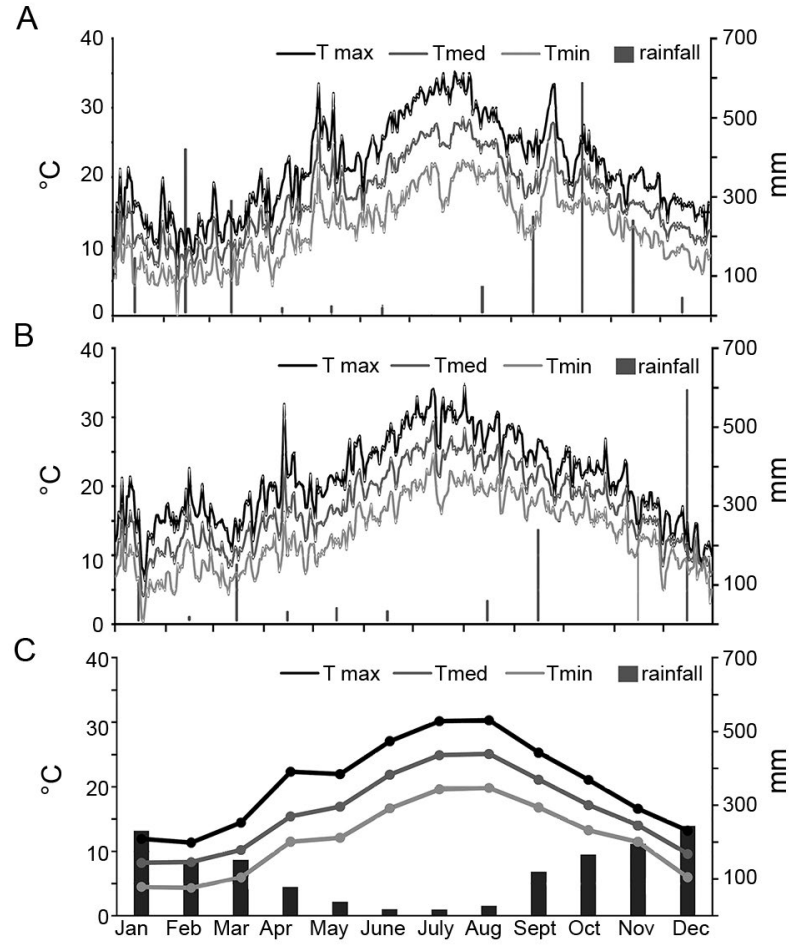

Figure 2 - Daily minimum, mean and maximum air temperatures and rainfall events in the experimental vineyard (lat. 37\% $41^{\prime} 13^{\prime \prime}$ $\mathrm{N}$; long. $15^{\circ} 07^{\prime} 00^{\prime \prime} \mathrm{E}$; elevation $602 \mathrm{~m}$ a.s.I.) and long-term (30 years) monthly mean values (A - 2015, B - 2016, C - 1985-2014).

(> $100 \mathrm{~mm}$ of rain). The solar radiation values were provided by the Siciliana Agrometereological System (www. sias.regione.sicilia.it).

Soil was characterized at three different depths: $10-30 \mathrm{~cm}, 30-50 \mathrm{~cm}$ and $50-70 \mathrm{~cm}$. According to the USDA scheme (Klingebiel and Montgomery, 1961) the vineyard soil was classified as loamy-sand at each depth. Briefly, the soil $\mathrm{pH}$ is neutral, the active carbonate is absent and the organic matter content is > $2 \%$ (data not shown).

\section{Treatment and leaf and shoot measurements}

(i) Early basal defoliation (EBD): All leaves were removed by hand from the shoot base (cordon) to the leaf just above the most distal cluster; (ii) Control (C): No leaves were removed. The EBD treatment was imposed two weeks after emergence of the inflorescence (principal growth stage n. 6: flowering; $\mathrm{BBCH}$ 61) (Lorenz et al., 1994). At this stage, we recorded the total numbers and areas of the leaves removed from the main and lateral shoots (Table 1). Leaf areas were measured using a Leaf Area Meter. We calculated the total remaining leaf area (TLA) per vine, the removed leaf area per vine, per main shoot and per lateral shoot and their percentages as described by Nicolosi et al. (2012). The lengths of the main and lateral shoots were also measured. 
Table 1 - Main morphological parameters registered on early basal defoliated vines.

\begin{tabular}{lcc}
\hline \multirow{2}{*}{ Parameter } & \multicolumn{2}{c}{ Year } \\
\cline { 2 - 3 } & 2015 & 2016 \\
\hline Total leaves removed $(\mathrm{n})$ & $94 \pm 13$ & $89 \pm 8$ \\
Leaves removed from main shoots $(\mathrm{n})$ & $44 \pm 7$ & $52 \pm 916$ \\
Leaves removed from lateral shoots $(\mathrm{n})$ & $49 \pm 8$ & $37 \pm 7$ \\
Mean leaf area removed $\left(\mathrm{cm}^{2}\right)$ & $226 \pm 17$ & $177 \pm 17$ \\
Main shoots mean leaf area removed $\left(\mathrm{cm}^{2}\right)$ & $134 \pm 9$ & $114 \pm 12$ \\
Lateral shoot mean leaf area removed $\left(\mathrm{cm}^{2}\right)$ & $92 \pm 0.8$ & $64 \pm 11$ \\
Main shoots $(\mathrm{n})$ & $7 \pm 1$ & $6 \pm 0.8$ \\
Main shoot leaves $(\mathrm{n})$ & $26 \pm 5$ & $23 \pm 4$ \\
Lateral shoots $(\mathrm{n})$ & $5 \pm 0.9$ & $5 \pm 0.9$ \\
Lateral shoot leaves $(\mathrm{n})$ & $13 \pm 2$ & $12 \pm 2$ \\
\hline
\end{tabular}

\section{Physiological measurements}

Mid-day leaf water potential $\left(\Psi_{L}\right)$, leaf gas exchange and leaf SPAD index (amount of chlorophyll) were measured every 15 days from day of year (DOY) 181 (early summer) to DOY 256. The $\Psi_{\mathrm{L}}$ measurements were taken on nine, fully-expanded leaves using a Schöelander pressure chamber according to Matthews et al. (1987). At least $2 \mathrm{~h}$ before detachment from the vine, leaves were enclosed in small, black, hermetic plastic bags covered with aluminium foil. Nine replicates per treatment were measured selecting three leaves from each plot. Net photosynthesis (Pn), stomatal conductance (gs) and transpiration (E) rates of well-exposed, mature primary leaves were measured with a portable photosynthesis system. Nine leaves per plot inserted on the apical portion of each shoot were tagged and sampled. At each measurement, these leaves were monitored during the morning (10h00-12h00) on sunny days $(\sim 1500 \mu \mathrm{mol}$ $\left.\mathrm{m}^{-2} \mathrm{~s}^{-1}\right)$ and had similar VPDmax $(3.25 \pm 0.25 \mathrm{kPa})$. The instrument was run in constant flow mode $\left(500 \mu \mathrm{mol} \mathrm{s}^{-1}\right)$ and sample $\mathrm{CO}_{2}$ concentration was held constant at 370 ppm using a mini $\mathrm{CO}_{2}$ cartridge. A portable chlorophyll meter was used to measure the SPAD index. Data was collected on each measurement date from nine fully exposed main and lateral leaves.

\section{Crop yield and biochemical analysis}

The crops were harvested on 5 Oct in 2015 and 10 Oct in 2016. For yield assessment, the clusters on the index vines were counted and weighed. Total yields per vine and per shoot were determined. In the laboratory samples of nine clusters per plot were used to determine cluster length and weight, numbers and weights of berries, rachis and skin weights.

A 100-berry sample of the index plants per experimental unit was divided into three sub-samples. The first sub-sample was used to determine the concentration of total soluble solids (TSS) (as ${ }^{\circ}$ Brix using a digital refractometer with temperature correction), the $\mathrm{pH}$ and the titratable acidity (TA) expressed as $\mathrm{g} \mathrm{L}^{-1}$ of tartaric acid equivalents, using an automatic titrator with $5.0 \mathrm{~mL}$ juice samples titrated against $0.1 \mathrm{M} \mathrm{NaOH}$ to $\mathrm{pH}$ 8.2.
The second subsample was used to determine total polyphenols, expressed as mg of gallic acid equivalent (GAE) $100 \mathrm{~g}^{-1}$ of berries and measured using the Folin-Ciocalteu reagent assay (Singleton et al., 1999). The third subsample was used to measure total anthocyanins and flavonoids expressed as $\mathrm{mg} \mathrm{kg}^{-1}$ fresh weight as described by Ferlito et al. (2014).

\section{Statistical analyses}

Analysis of variance (ANOVA) and mean separations by Tukey's post hoc test were carried out using STATISTICA 6.0 statistical software. Significant treatment and genotype effects were shown by a factorial analysis of variance. Statistically significant differences were represented as $p$ values that define the probability that an observation indicates a true relationship between factors. Results are marked $*, * *$ or $* * *$, referring to $p \leq 0.05, p \leq 0.01$ or $p \leq 0.001$, respectively. In order to determine the relationships between the indicators, we carried out a Spearman's rank-order correlation analysis applying the non-parametric version of the Pearson correlation using the same statistical software. A principal component analysis (PCA) was carried out on a dataset including yield components, morphological data and cluster biochemical characteristics of EBD and C vines to represent a multidimensional dataset, with the lowest number of variables explaining the main features of the dataset. PCA was carried out using PAST (Paleontological Statistics software package, 2001).

\section{Results}

\section{Climate variables}

The annual average temperature was $17{ }^{\circ} \mathrm{C}$ (Figures $2 \mathrm{~A}, \mathrm{~B}$ and C). During the two years of the study the lowest minimum temperatures were recorded in Jan and Feb. July was the hottest month (mean daily maximum temperature $25.9^{\circ} \mathrm{C}$ in 2015 and $25.4^{\circ} \mathrm{C}$ in 2016). Mean daily maximum temperature values were always above $23{ }^{\circ} \mathrm{C}$ from June to Sept and above $14.5^{\circ} \mathrm{C}$ from Mar to May. Annual rainfall was about 2,000 $\mathrm{mm}$ in 2015 and $1,500 \mathrm{~mm}$ in 2016 . No rainfall was recorded in July in either year, Aug rainfall was $66 \mathrm{~mm}$ in 2015 and $49 \mathrm{~mm}$ in 2016 and Sept rainfall was $240 \mathrm{~mm}$ in 2015 and 230 $\mathrm{mm}$ in 2016. The solar radiation levels are somewhat high in both years. Values ranged between 25 and $30 \mathrm{MJ}$ $\mathrm{m}^{-2}$ from Apr to the end of Aug (Figure 3).

\section{Early Basal Defoliation}

After defoliation, the fraction of canopy leaf area remaining was $67 \%$ in 2015 and $58 \%$ in 2016. The lower fraction of remaining leaf in 2016, derived from the low value of TLA per vine. The low TLA per vine was due to smaller and fewer leaves, and not shorter shoots (shoot lengths were similar in the two years). The leaf area/vine removed was $10,400 \mathrm{~cm}^{2}$ in 2015 and 8,500 $\mathrm{cm}^{2}$ in 2016 (a difference of approximately 1,900 $\mathrm{cm}^{2}$ ) while the reduction in total leaf area/vine was 11,500 
$\mathrm{cm}^{2}$ in 2016 year (64\% less). These percentages are due to the removal of $14 \%$ (2015) and $15 \%$ (2016) of leaves per shoot. The EBD had an effect on lateral leaf growth causing both TLA and removed leaf area to decrease in area terms but increased in percentage terms (Table 2).

\section{Physiological measurements}

Compared with the $\mathrm{C}$ vines, the $\mathrm{EBD}$ vines showed higher water status (less negative midday leaf water potential) at all times for both years (Figures 4A and $\mathrm{B})$. At the beginning and the end of the water potential monitoring period in the first year, there were no differences between the mid-day leaf water potentials of the EBD and $C$ vines, but in the second year, the EBD vines had higher water staus at the first monitoring in June. In the period from DOY 211 to DOY 241 (from veraison to ripening) mid-day leaf water protential differences between EBD and $\mathrm{C}$ vines were registered. In
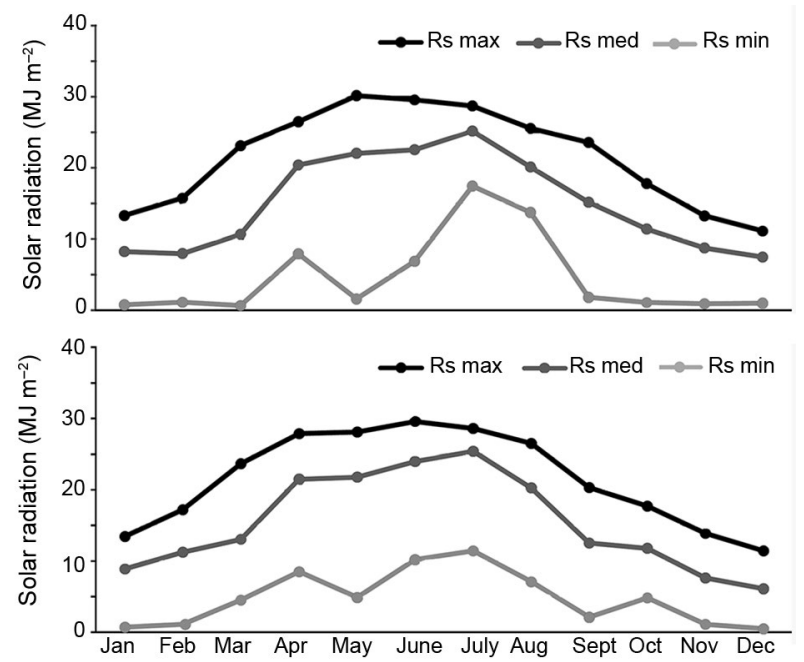

Figure 3 - Monthly minimum, mean and maximum global radiation in the experimental vineyard (lat. $37^{\circ} 41^{\prime} 13^{\prime \prime} \mathrm{N}$; long. $15^{\circ} 07^{\prime} 00^{\prime \prime} \mathrm{E}$; elevation $602 \mathrm{~m}$ a.s.I.). the EBD vines, midday leaf water potential remained above $-0.8 \mathrm{MPa}$ in 2015 , falling to $-0.8 \mathrm{MPa}$ only at DOY 226. In 2015, the midday leaf water potential of the $\mathrm{C}$ vines reached -0.8 $\mathrm{MPa}$ somewhat earlier, at DOY 211 and stayed below this value until DOY 241. In 2016, mid-day leaf water potential fell to $-0.8 \mathrm{MPa}$ for $\mathrm{C}$ vines quite early, at DOY 196, and remained low until berry ripening (DOY 256).

Compared with the $\mathrm{C}$ vines, the EBD vines showed higher rates of net photosynthesis, stomatal conductance and transpiration in both years (Figure 5A-F). In 2015, differences were recorded in these values from
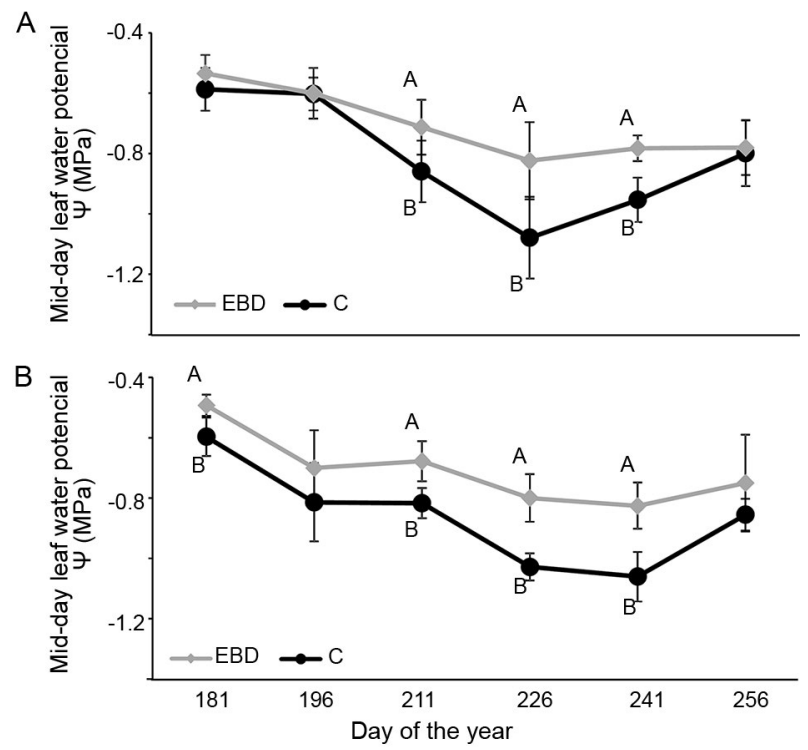

Figure 4 - Mid-day leaf water potential $\left(\Psi_{\text {stem }}\right)$ measured in vines subject to early basal defoliation (EBD) and in control vines (C), in 2015 (A) and 2016 (B). For each year, treatment and day of year, means indicated by different lowercase letters are significantly different ( $p \leq 0.001$ ) based on Tukey's HSD test (error bars indicate standard deviations).

Table 2 - Intensity and incidence of early basal defoliation on vines.

\begin{tabular}{|c|c|c|}
\hline \multirow{2}{*}{ Parameter } & \multicolumn{2}{|c|}{ Year } \\
\hline & 2015 & 2016 \\
\hline Total leaf area/vine $\left(\mathrm{cm}^{2}\right)$ & $32,000 \mathrm{~A} \pm 9,700$ & $20,500 B \pm 3,970$ \\
\hline Removed leaf area/vine $\left(\mathrm{cm}^{2}\right)$ & $10,400 \mathrm{~A} \pm 1,940$ & $8,500 \pm 1,160$ \\
\hline Removed leaf area/vine (\%) & $35 \pm 17$ & $43 \pm 9$ \\
\hline Main shoot length $(\mathrm{cm})$ & $116 \pm 2$ & $117 \pm 4$ \\
\hline Total leaf area main shoot $\left(\mathrm{cm}^{2}\right)$ & $3,470 A \pm 852$ & $2,600 B \pm 431$ \\
\hline Removed leaf area/main shoot $\left(\mathrm{cm}^{2}\right)$ & $874 \pm 327$ & $1,020 \pm 216$ \\
\hline Removed leaf area/main shoot (\%) & $27 b \pm 16$ & $40 \mathrm{a} \pm 10$ \\
\hline Lateral shoot length $(\mathrm{cm})$ & $28 \pm 7$ & $26 \pm 5$ \\
\hline Total leaf area lateral shoot $\left(\mathrm{cm}^{2}\right)$ & $1,140 \mathrm{~A} \pm 123$ & $730 \mathrm{~B} \pm 170$ \\
\hline Removed leaf area/lateral shoot $\left(\mathrm{cm}^{2}\right)$ & $844 A \pm 200$ & $450 \mathrm{~B} \pm 109$ \\
\hline Removed leaf area/lateral shoot (\%) & $74 \mathrm{~A} \pm 16$ & $64 \mathrm{~B} \pm 20$ \\
\hline
\end{tabular}



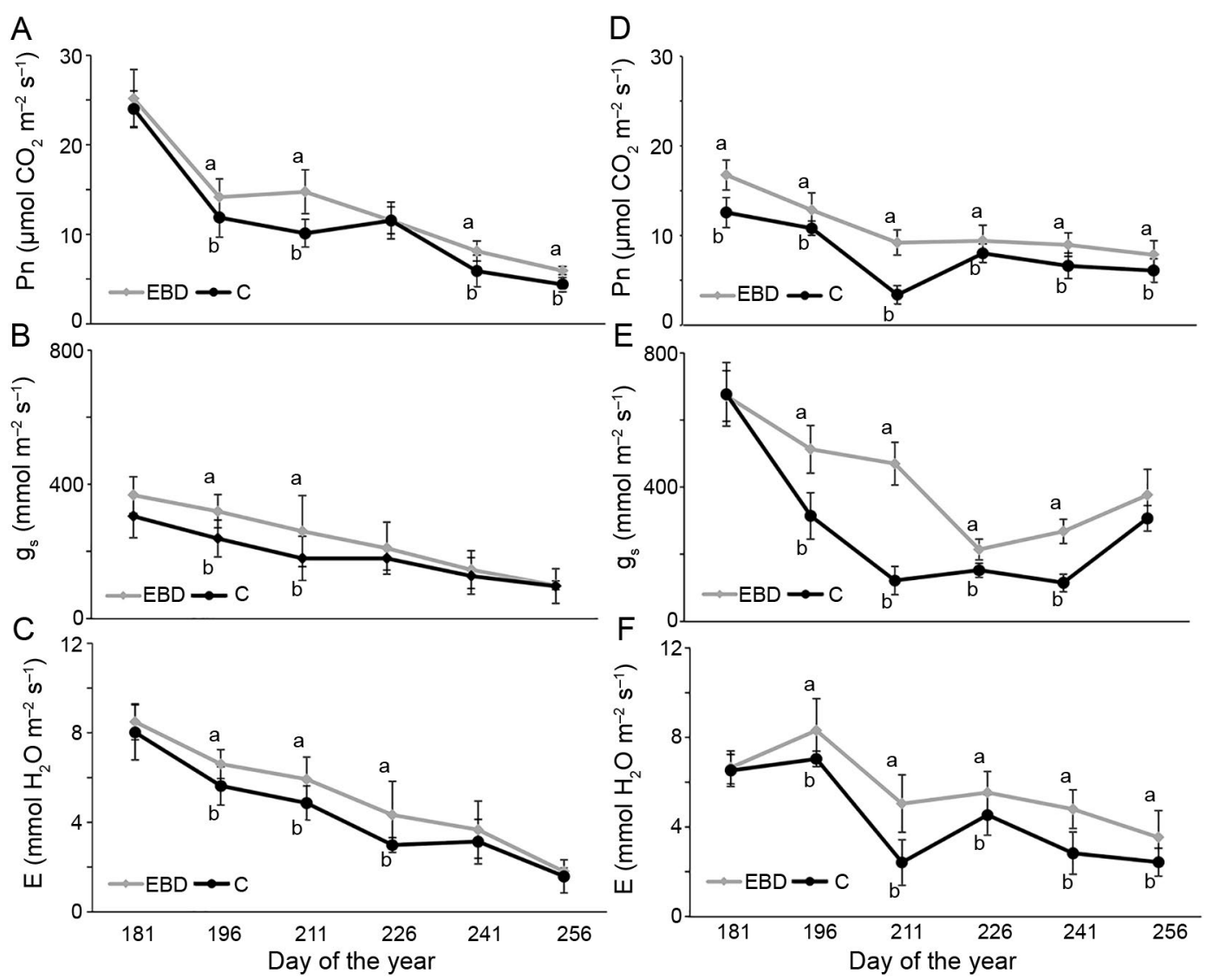

Figure 5 - Net photosynthesis $\left(P_{n}\right)$, stomatal conductance (gs) and transpiration (E) measured in early basal defoliation (EBD) and control vines (C), in 2015 ( $A, B, C)$ and $2016(D, E, F)$. For each year, treatment and day of year means indicated by different lowercase letters are significantly different $(p \leq 0.05)$ based on Tukey's HSD test (error bars indicate standard deviations).

DOY 196 onwards. Compared with the C vines, in the EBD vines, $P_{n}$ was higher till the last measurement in Sept (with the exception of the measurement on DOY 226). Meanwhile, values of $g_{s}$ were different till DOY 211, and those of E were different till DOY 226. In 2016, all gas exchange values for the EBD vines were higher from DOY 196 to DOY 256. As the season progressed, a worsening of all gas exchange values was seen in both years but these were generally lower in 2016. This was probably due to the higher average temperatures in the second year. Compared to the $\mathrm{C}$ vines, the SPAD index values in the EBD vines were generally more favorable in the leaves of both the main shoots and the laterals (Figure 6A-D). In both years SPAD differences between vines were recorded for the main leaves only (in 2015 at each date).

\section{Yield and biochemical analyses}

In 2015 and 2016, compared with the $C$ vines, vine productive performance in the EBD vines was not different. Thus, there was no influence of EBD or year, and no interaction between factors. Similarly, there were no differences in yield/main shoot. However, cluster weights in 2015 were considerably higher in the EBD vines than the $\mathrm{C}$ ones, but no differences were recorded in 2016. The EBD also had no effect on yield/main shoot. Conversely, an increase in cluster weight was detected in 2015 and a year vs treatment effect was also found. The EBD treatment influenced cluster length in 2015 but not in 2016. There were no differences in berry weight with EBD but the difference between one year and the next was noted as was also observed in the case of the strong effect of EBD treatment on the rachis weight, in addition to increased skin weight (Table 3). The TSS did not increase in the EBD vines in either year, while the TA showed a difference. In the first year TA was generally higher in the EBD vines while in 2016 it decreased with the metereological trend characterized by a strong increase in rainfall (Table 3 ).

The EBD treatment improved the quality attributes including the contents of total polyphenols, total flavonoids and total anthocyanins. In 2015 only the total polyphenols increased, while in 2016 all the quality attributes showed improvement. In 2016, both EBD and $\mathrm{C}$ vines showed a general decrease in their quality attributes (Figure 7A and B). 
A
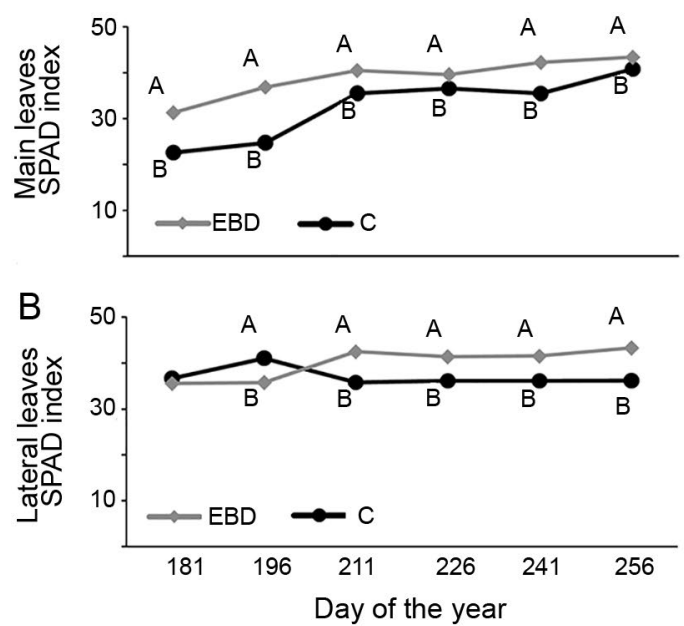

C
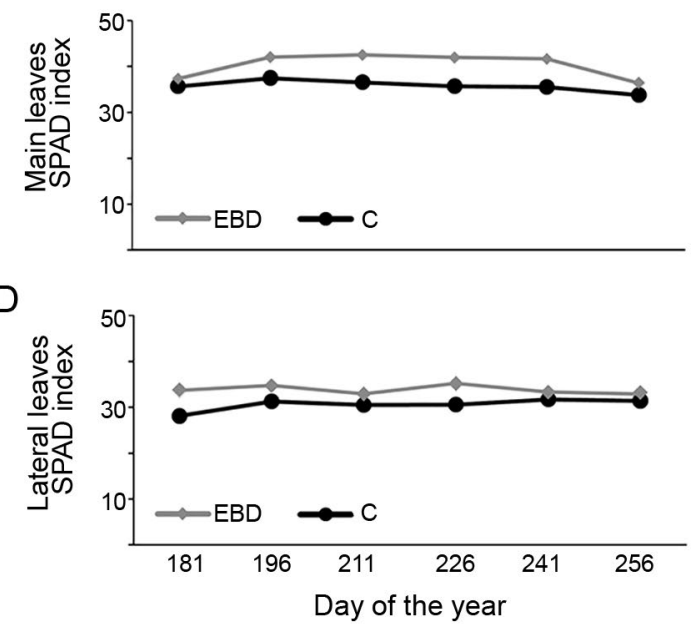

Figure 6 - SPAD index measured in early basal defoliated (EBD) and control (C) vines in main and lateral leaves. 2015 (A, B) and 2016 (C, D). For each year, treatment and day of year means indicated by different lowercase letters are significantly different $(p \leq 0.001)$ based on Tukey's HSD test (error bars indicate standard deviations).

Table 3 - Influence of early basal defoliation on yield characteristics and main berry quality attributes.

\begin{tabular}{|c|c|c|c|c|c|c|c|}
\hline \multirow{2}{*}{ Parameters } & \multicolumn{2}{|c|}{2015} & \multicolumn{2}{|c|}{2016} & \multicolumn{3}{|c|}{ Interactions } \\
\hline & Early basal defoliation & Control & Early basal defoliation & Control & Treatment (T) & Year $(Y)$ & $T \times Y$ \\
\hline Yield/vine (kg) & $2.44 \pm 0.36$ & $2.46 \pm 0.42$ & $1.94 \pm 0.32$ & $2.14 \pm 0.36$ & & & \\
\hline Yield/main shoot (kg) & $0.36 \pm 0.13$ & $0.42 \pm 0.11$ & $0.32 \pm 0.07$ & $0.36 \pm 0.11$ & & & \\
\hline Cluster weight (g) & $298.22 a \pm 64.95$ & $233.33 b \pm 30.96$ & $318.14 \pm 74.48$ & $319.79 \pm 70.11$ & & $\star * *$ & ** \\
\hline Cluster length (cm) & $16.72 \pm 1.60$ & $15.95 \pm 1.42$ & $18.22 \pm 2.03$ & $16.85 \pm 1.39$ & * & * & \\
\hline Berries number & $106.67 \pm 32.33$ & $112.67 \pm 35.69$ & $130.78 \pm 20.34$ & $139.33 \pm 30.04$ & & * & \\
\hline Berry weight (g) & $2.60 \pm 0.42$ & $2.62 \pm 0.36$ & $2.81 \pm 0.08$ & $2.86 \pm 0.09$ & & * & \\
\hline Rachis weight (g) & $8.38 \pm 3.62$ & $9.64 \pm 3.87$ & $26.26 \mathrm{~B} \pm 0.44$ & $32.89 A \pm 2.24$ & $* * *$ & $* * *$ & ** \\
\hline Skin weight (g) & $0.19 \pm 0.02$ & $0.17 \pm 0.07$ & $0.54 \mathrm{~A} \pm 0.08$ & $0.42 \mathrm{~B} \pm 0.03$ & & $\star \star * *$ & \\
\hline Total soluble solids ( ${ }^{\circ}$ Brix) & $21.94 \pm 1.07$ & $20.79 \pm 1.23$ & $21.66 \pm 1.23$ & $21.49 \pm 0.66$ & & & \\
\hline $\mathrm{pH}$ & $3.25 \pm 0.10$ & $3.31 \pm 0.13$ & $3.27 \pm 0.07$ & $3.27 \pm 0.06$ & & & \\
\hline Titratable acidity (g $100 \mathrm{~mL}^{-1}$ ) & $1.15 \pm 0.15$ & $0.93 \pm 0.15$ & $0.71 \pm 0.07$ & $0.76 \pm 0.14$ & & ** & \\
\hline
\end{tabular}

For each year and parameter, means indicated by different letters are significantly different (lowercase letters: $p \leq 0.05$; uppercase letters: $p \leq 0.001$ ) based on Tukey's HSD test within year ( \pm standard deviation). Interactions are indicated by: ${ }^{\star}$ Significant $p<0.05 ;{ }^{*}$ Significant $p<0.01 ;{ }^{* *}$ Significant $p<0.001$.

According to Spearman's analysis we found significant correlation between the variables related to the size of the bunch, as expected. Rachis and skin weight also showed significant correlation $(p \leq 0.05)$ with the majority of the qualitative traits studied (Table 4). In particular, the rachis weight was strongly negative correlation with anthocyanins $\left(r_{s}=-0.70\right)$ and moderately with flavonoids, polyphenols and titratable acidity $\left(\mathrm{r}_{\mathrm{s}}\right.$ $=-0.55,-0.45$ and -0.53 , respectively; $p \leq 0.05)$. Skin weight was strongly positively correlated with anthocyanins and flavonoids $\left(r_{s}=0.61\right.$ and 0.63$)$, and moderately with polyphenols and titratable acidity $\mid \mathrm{r}_{\mathrm{s}}=0.40$ and 0.46 , respectively).

The PCA analyses (Figure 8) were carried out on a dataset, that included yield components, morphological data and cluster biochemical characteristics collected over the two-year trial (2015-2016) on EBD and C vines.
Four principal components were extracted with eigenvalues $\geq 1$. These accounted for $72 \%$ of the total variance. The first two components accounted for $51 \%$ of the total variance. The PCA displays the relationships between the samples based on similarity in pattern of their original attributes leading to the highlighting of a number of groupings. All the 2015 observations were included in the positive part of PC1 (35\% of the variance) and all the 2016 observations had negative scores. In the positive part of PC1 there was no separation between the EBD and C samples of 2015, whereas for 2016 the EBD and C samples were well separated. To identify the variables driving this pattern we generated a biplot (Figure 9). The first principal component was positively and well correlated with skin weight $(\mathrm{r}=0.8706)$, anthocyanins $(\mathrm{r}=0.7687)$, flavonoids $(\mathrm{r}=0.6225)$ and polyphenols $(\mathrm{r}=0.5778)$ while negative and less strong correla- 
tions were found with rachis weight $(\mathrm{r}=-0.9499)$, berry number $(\mathrm{r}=-0.5972)$, cluster weight $(\mathrm{r}=-0.5643)$ and berry weight $(\mathrm{r}=-0.5164)$. These variables discriminated between years, with small clusters with increased concentrations of antioxidants, alternating with higher yields with lower levels of antioxidants. In 2016, the separation between EBD and $\mathrm{C}$ was instead related to the variables associated with cluster size, including rachis weight, berry number, cluster weight and berry weight. The PC2 (16\% of the variance) showed a certain nega-

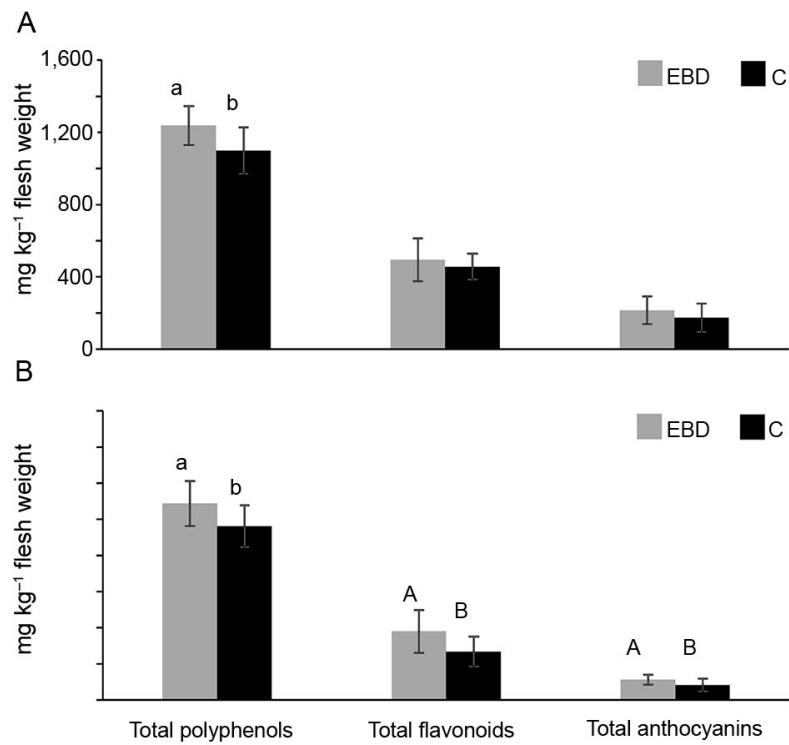

Figure 7 - Total polyphenols, flavonoids and anthocyanins measured in early basal defoliated (EBD) and control (C) vines in 2015 (A) and 2016 (B). For each year, treatment and parameter columns indicated by different lowercase letters are significantly different ( $p$ $\leq 0.05$ ) or numerals $(p \leq 0.001)$ based on Tukey's HSD test (error bars indicate standard deviations).

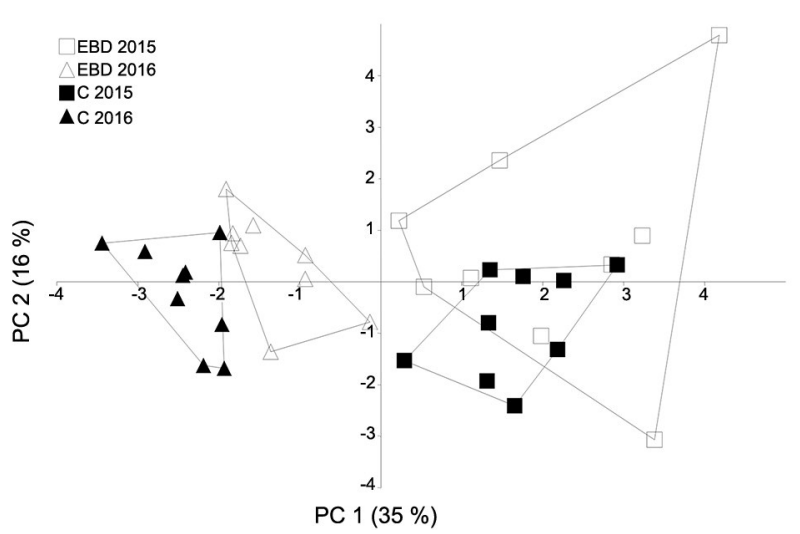

Figure 8 - Scatter plot with convex hulls of the Principal Component Analysis (PCA) carried out on the dataset collected during the twoyear trial (2015-2016) on early basal defoliated (EBD) and control (C) vines.

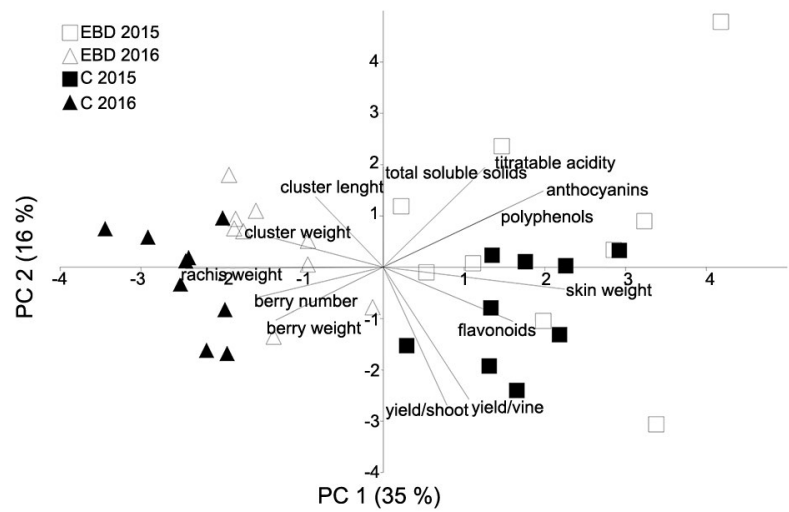

Figure 9 - Biplot of the Principal Component Analysis (PCA) carried out on the dataset collected during the two-year trial period (20152016) on early basal defoliated (EBD) and control (C) vines.

Table 4 - Spearman's rank-order correlation, significant correlations $\left(r_{s}\right)$ for $p \leq 0.05$ are shown in bold characters.

\begin{tabular}{|c|c|c|c|c|c|c|c|c|c|c|c|c|c|}
\hline Parameter & $\begin{array}{l}\text { Yield/ } \\
\text { vine }\end{array}$ & $\begin{array}{c}\text { Yield/ } \\
\text { main shoot }\end{array}$ & $\begin{array}{l}\text { Cluster } \\
\text { t weight }\end{array}$ & $\begin{array}{l}\text { Cluster } \\
\text { length }\end{array}$ & $\begin{array}{l}r \text { Berries } \\
\text { number }\end{array}$ & $\begin{array}{l}\text { Berry } \\
\text { weight }\end{array}$ & $\begin{array}{l}\text { Rachis } \\
\text { t weight }\end{array}$ & $\begin{array}{c}\text { Skin } \\
\text { weight }\end{array}$ & $\begin{array}{l}\text { Total soluble } \\
\text { solids }\end{array}$ & $\begin{array}{c}\text { Titratable } \\
\text { acidity }\end{array}$ & $\begin{array}{c}\text { Total } \\
\text { polyphenols }\end{array}$ & $\begin{array}{c}\text { Total } \\
\text { anthocyanins }\end{array}$ & $\begin{array}{c}\text { Total } \\
\text { flavonoids }\end{array}$ \\
\hline & $\longrightarrow$ & $-\mathrm{kg}-$ & $-g$ & $\mathrm{~cm}$ & & $\longrightarrow$ & $-\mathrm{g}$ & 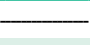 & ${ }^{\circ}$ Brix & g $100 \mathrm{~mL}^{-1}$ & & $-\mathrm{mg} \mathrm{kg}^{-1}$ & \\
\hline Yield/vine (kg) & 1.00 & 0.82 & -0.02 & -0.07 & -0.21 & -0.18 & -0.31 & 0.35 & -0.23 & 0.23 & 0.19 & -0.02 & 0.39 \\
\hline Yield/main shoot (kg) & 0.82 & 1.00 & -0.13 & -0.13 & -0.20 & -0.20 & -0.27 & 0.26 & -0.23 & 0.06 & 0.10 & -0.12 & 0.29 \\
\hline Cluster weight (g) & -0.02 & -0.13 & 1.00 & 0.68 & 0.17 & 0.18 & 0.51 & -0.52 & 0.04 & -0.17 & -0.03 & -0.44 & -0.35 \\
\hline Cluster lenght (cm) & -0.07 & -0.13 & 0.68 & 1.00 & 0.12 & 0.24 & 0.22 & -0.24 & 0.02 & -0.09 & 0.17 & -0.12 & -0.12 \\
\hline Berries number & -0.21 & -0.20 & 0.17 & 0.12 & 1.00 & 0.35 & 0.56 & -0.41 & -0.25 & -0.23 & -0.04 & -0.41 & -0.24 \\
\hline Berry weight (g) & -0.18 & -0.20 & 0.18 & 0.24 & 0.35 & 1.00 & 0.55 & -0.28 & -0.02 & -0.35 & -0.36 & -0.31 & -0.23 \\
\hline Rachis weight (g) & -0.31 & -0.27 & 0.51 & 0.22 & 0.56 & 0.55 & 1.00 & -0.84 & -0.03 & -0.53 & -0.45 & -0.70 & -0.55 \\
\hline Skin weight (g) & 0.35 & 0.26 & -0.52 & -0.24 & -0.41 & -0.28 & -0.84 & 1.00 & -0.12 & 0.46 & 0.40 & 0.61 & 0.63 \\
\hline Total soluble solids ('Brix) & -0.23 & -0.23 & 0.04 & 0.02 & -0.25 & -0.02 & -0.03 & -0.12 & 1.00 & 0.00 & 0.04 & 0.00 & -0.03 \\
\hline Titratable acidity (g $100 \mathrm{~mL}^{-1}$ ) & 0.23 & 0.06 & -0.17 & -0.09 & -0.23 & -0.35 & -0.53 & 0.46 & 0.00 & 1.00 & 0.38 & 0.48 & 0.23 \\
\hline Total polyphenols (mg kg-1) & 0.19 & 0.10 & -0.03 & 0.17 & -0.04 & -0.36 & -0.45 & 0.40 & 0.04 & 0.38 & 1.00 & 0.56 & 0.27 \\
\hline Total anthocyanins (mg kg-1) & -0.02 & -0.12 & -0.44 & -0.12 & -0.41 & -0.31 & -0.70 & 0.61 & 0.00 & 0.48 & 0.56 & 1.00 & 0.36 \\
\hline Total flavonoids (mg kg-1) & 0.39 & 0.29 & -0.35 & -0.12 & -0.24 & -0.23 & -0.55 & 0.63 & -0.03 & 0.23 & 0.27 & 0.36 & 1.00 \\
\hline
\end{tabular}


tive correlation with yield per main shoot $(\mathrm{r}=-0.7079)$ and yield per vine $(\mathrm{r}=-0.6773)$ and a slight positive correlation with TA $(\mathrm{r}=0.5272)$ and TSS $\left({ }^{\circ} \mathrm{Brix}\right)(\mathrm{r}=$ -0.5144 ) but no groups stood out particularly strongly.

\section{Discussion}

In line with similar studies on EBD, canopy management has been shown to influence grape yield and quality attributes (Teixeira et al., 2013). In a previous study in a warmer area, we identified the beneficial effects of early leaf removal for yield control, mainly in less vigorous cultivars, and also for improved color in the exposed clusters. Moreover, common endemic diseases were better contained due to freer air circulation (Nicolosi et al., 2012; Ferlito et al., 2014). In this study, the EBD was carried out in a vineyard characterised by a loamy-sand, sub-acid and rich in organic matter soil. This is located in an area of Mount Etna that is generally cooler than coastal areas and wetter during the latter stages of berry ripening from mid Aug to Sept. These conditions, together with the high level of solar radiation for a relatively long season including most of the vine's flowering-ripening stages, allow for the attaining of very high qualitative traits in berries, in terms of pigmentation and sugar content. After EBD, the total leaf area per vine was very different in the two years of this study, mostly the result of reduced cultivar vigor and productivity (Bekar et al., 2017). This effect lasts for at least two years (Bledsoe et al., 1988) where reduced vigor is a result of lowered carbohydrate reserves. The EBD applied in the early stage of the flowering clearly changed the leaf area / fruit yield ratio. Despite this, it was proposed as a useful tool for yield regulation and quality improvement (Ferlito et al., 2014). In our trial, the effect on yield was negligible, the percentages of leaf removal (33\% and $42 \%)$ did not affect yield. This contrasts with the findings of Hunter and Visser (1990) who found a lower yield with $33 \%$ defoliation during early fruit development (before pea size) and $66 \%$ defoliation before veraison. These conflicting results may be related to the trial location - a cooler area and despite the berries being well exposed to the sun, the duration of exposure was shorter being located on an eastern slope. These results agree with those reported by Bledsoe et al. (1988) for a cooler region. Here, 'Nerello mascalese' is considered a mid-high vigor vine and at our location the period leading up to full ripening (between the end of Sept and the first week of Oct) is usually mild and with frequent rain (Figure 1). Under these conditions berry weight can increase rapidly.

The role played by the lateral shoots in the vine response to EBD would seem to be important. The percentage of leaf area removed was very high $174 \%$ in 2015 and $64 \%$ in 2016) even though this involved only basal leaves. The early timing of the EBD meant that these basal leaves were the only fully developed leaves on the vine. During the following weeks, the laterals from the upper productive canopy grew very rapidly, greatly increasing vine leaf area. This behavior has previously been noted by Poni et al. (2006) who observed significant increases in lateral shoot number as a result of severe early leaf removal. Generally, this response can influence canopy performance as shown by Candolfi-Vasconcelos and Koblet (1990) who reported that early defoliation caused an increase in leaf photosynthetic efficiency in the remaining leaves. This compensated for the stress of the early reduction in source/sink ratio (Pisciotta et al., 2013). In our trial, the effect explains the best photosynthetic efficiency expressed in terms of SPAD values registered in the main and lateral leaves of defoliated vines. Moreover, it is possible that this type of defoliation improves berry metabolic activity increasing their leaf photosynthesis as has been reported by Hunter and Visser (1990). As a consequence, according to Candolfi-Vasconcelos and Koblet (1990) and Bledsoe et al. (1988), this response to early defoliation did not have a strong effect on yield and its components. In 2016 defoliation caused an increase in skin weight. We suggest that the remaining leaves were well able to supply carbohydrates during berry growth (Intrieri et al., 2008) and this is probably advantageous in terms of protection against fungal diseases.

Despite the disturbance of the first stage of berry development by defoliation, the later performance of the vines was enhanced by elevated water status. From June until the harvest, the midday leaf water potential was above $-0.8 \mathrm{MPa}$. According to the literature, a reasonable mid-day leaf water potential value for a well-irrigated vine would be approximately $-0.8 \mathrm{MPa}$, while $-1.2 \mathrm{MPa}$ is considered moderately stressed and -1.5 severely stressed (Olivo et al., 2009; Intrigliolo et al., 2012; Triolo et al., 2018). The $\mathrm{C}$ vines showed at least moderate stress in mid-summer and their water status was worse than the EBD vines at the same stage. The differences in canopy management throughout the season indicate differences in vine evapotraspiration. Therefore, the reduced number of leaves in the EBD vines improved their efficiency. The EBD improved the fruit qualitative traits. Moderate water stress usually improves berry quality, although the mechanisms responsible are not clear and the response is not consistent from year to year (Girona et al., 2006).

The most important period for TSS increase is ripening (Coombe, 1995). The absence of differences in TSS, $\mathrm{pH}$ and TA probably depend on rainfall which in 2015 occured mainly in Sept. Nevertheless, despite there being no differences in qualitative parameters, the results indicate good ripeness at harvest for the EBD clusters.

The positive effects of EBD on total polyphenols, flavonoids and anthocyanins are interesting as these increased levels of biologically active substances are important both for the quality of wine as well as human health. Moreover, these qualitative parameters are positively correlated with skin weight (Table 4), suggesting 
a role for solar radiation on the ripening processes and skin/flesh ratio increase. The placement in the positive part of PC1 indicates these compounds were at higher levels than the 2015 samples, while the 2016 samples had heavier clusters with more berries. Tardaguilla et al. (2010) reported that EBD substantially increased phenol levels in the fruit and wine of two cultivars. In particular for 'Carignan', EBD resulted in heavier berries and enhanced grape and wine color. Also, much research has shown a correlation between berry light exposure and the accumulation of flavonols (Spayd et al., 2002). However, it is very difficult to establish a direct effect of defoliation on flavonol accumulation as there are numerous factors involved in their synthesis (Downey et al., 2006). Despite the reported negative effects of excessive light exposure on flavonol accumulation (Chorti et al., 2010), in our study, exposure of the fruit to sunlight seems to be the main factor responsible for the increase in flavonol, as had also been reported by Spayd et al. (2002). Flavonol accumulation probably also influences total anthocyanins, since despite flavonols being colourless, their action is explained as a co-pigment for anthocyanins (Downey et al., 2003a). This correlation suggests these compounds are synthesised together. This is somewhat surprising given that the effects of light and temperature are opposite-going in respect of the synthesis of these compounds. However, the above interactions are eliminated because flavonol accumulation occurs during flowering and from 15 days after veraison until ripening (Downey et al., 2003b), while anthocyanins are synthesised from veraison until full ripening (Lo Cicero et al., 2016). The latter period is certainly cooler and thus no temperature limitations were observed. Moreover, it is generally true that with low yields/vine, anthocyanins usually increase (Petrie and Clingeleffer, 2006).

\section{Conclusion}

In Nerello mascalese, the most important black variety in the Mount Etna district, the effectiveness of EBD in modifying important physiological and qualitative parameters was demonstrated. As for the physiological parameters, the vines subjected to EBD showed a better water status and higher levels of photosyntetic efficiency during berry growth and ripening and did not exhibit any reduction in yield. Leaves from laterals in EBD vines were able to supply carbohydrates during berry growth in both years after treatment. On the other hand, EBD had strong positive effects on berry quality attributes which were particularly significant for total polyphenols, anthoncyanins and flavonoids. This was probably due to better cluster exposure to the sun coupled with improved vine water status and (for the anthocyanins) no excessive temperatures in the last phase of ripening. Although fungal disease was not a factor recorded in this study, at no stage did we see any evidence of disease in leaves or clusters of either EBD or $\mathrm{C}$ vines.

\section{Acknowledgments}

The authors would like to thank the farmers Costa and Indelicato for hosting the trials.

\section{Authors' Contributions}

Conceptualization: Ferlito, F.; Nicolosi, E. Data acquisition: Ferlito, F.; Allegra, M.; Continella, A.; Stagno, F.; Nicolosi, E. Data analysis: Ferlito, F.; Allegra, M.; Torrisi, B.; Continella, A.; Stagno, F.; Nicolosi, E.; Pappalardo, H. Design of metodology: Ferlito, F.; Gentile, A.; La Malfa, S.; Nicolosi, E. Software development: Ferlito, F.; Allegra, M.; Nicolosi, E. Writing and editing: Ferlito, F.; Continella, A.; Gentile, A.; La Malfa, S.; Nicolosi, E.

\section{References}

Bekar, T.; Bayram, M.; Cangi, R.; Gen, N.; Elmasta, M. 2017. Effects of leaf removals on must and wine chemical composition and phenolic compounds of Narince (Vitis vinifera) grape cultivar. Scientia Horticulturae 225: 343-349.

Bledsoe, A.M.; Kliewer, W.M.; Marois, J.J. 1988. Effects of timing and severity of leaf removal on yield and fruit composition of Sauvignon Blanc grapevines. American Journal of Enology and Viticulture 1: 49-54.

Candolfi-Vasconcelos, M.C.; Koblet, W. 1990. Yield, fruit quality, bud fertility and starch reserves of the wood as a function of leaf removal in Vitis vinifera: evidence of compensation and stress recovering. Vitis 29: 199-221.

Coombe, B. 1995. Growth stages of the grapevine. Australian Journal of Grape and Wine Research 1: 100-110.

Chorti, E.; Guidoni, S.; Ferrandino, A.; Novello, V. 2010. Effect of different bunch sunlight exposure levels on ripening and anthocyanin accumulation in Nebbiolo grapes. American Journal of Enology and Viticulture 61: 23-30.

Downey, M.O.; Harvey, J.S.; Robinson, S.P. 2003a. Synthesis of flavonols and expression of flavonol synthase genes in the developing grape berries of Shiraz and Chardonnay (Vitis vinifera L.). Australian Journal of Grape and Wine Research 9: 110-121.

Downey, M.O.; Harvey, J.S.; Robinson, S.P. 2003b. Analysis of tannins in seeds and skins of Shiraz grapes throughout berry development. Australian Journal of Grape and Wine Research 9: $15-27$.

Downey, M.O.; Dokoozlian, N.K.; Krstic, M.P. 2006. Cultural practice and environmental impacts on the flavonoid composition of grapes and wine: a review of recent research. American Journal of Enology and Viticulture 57: 257-268.

Feng, H.; Skinkis, P.A.; Michael, C.Q. 2017. Pinot noir volatile and anthocyanin composition under different levels of vine fruit zone leaf removal. Food Chemistry 2014: 736-744.

Ferlito, F.; Nicolosi, E.; Gentile, A.; Lo Piero, A.R.; Squadrito, M.; Continella, A. 2014. Responses of four winegrape varieties to managed water stress and partial defoliation in an arid environment. Vitis 53: 73-80.

Girona, J.; Mata, M.; Del Campo, J.; Arbonés, A.; Bartra, E.; Marsal, J. 2006. The use of midday leaf water potential for scheduling deficit irrigation in vineyards. Irrigation Science 24: 115-127. 
Hunter, J.J.; Visser, J.H. 1988. The effect of partial defoliation, leaf position and developmental stage of the vine on the photosynthetic activity of Vitis vinifera (L.) cv. Cabernet Sauvignon. South African Journal of Enology and Viticulture 9: 9-15.

Hunter, J.J.; Visser, J.H. 1990. The effect of partial defoliation on growth characteristics of Vitis vinfera L. cv. Cabernet Sauvignon. II. Reproductive Growth. South Africa Journal of Enology and Viticulture 11: 26-32.

Intrieri, C.; Filippetti, I.; Allegro, G.; Centinari, M.; Poni, S. 2008. Early defoliation (hand vs mechanical) for improved crop control and grape composition in Sangiovese (Vitis vinifera L.). Australian Journal of Grape and Wine Research 14: 25-32.

Intrigliolo, D.S.; Perez, D.; Risco, D.; Yeves, A.; Castel, J.R. 2012. Yield components and grape composition responses to seasonal water deficits in Tempranillo grapevines. Irrigation Science 30: 339-349.

Klingebiel, A.A.; Montgomery, P.H. 1961. Land Capability Classification. Agriculture USDA, Washington, DC, USA. (Handbook, 210).

Kotseridis, Y.; Georgiadou, A.; Tikos, P.; Kallithraka, S.; Koundouras, S. 2012. Effects of severity of post-flowering leaf removal on berry growth and composition of three red Vitis vinifera (L.) cultivars grown under semiarid conditions. Journal of Agricultural and Food Chemistry 60: 6000-6010.

Lemut, S.M.; Trost, K.; Sivilotti, P.; Arapitsas, P.; Vrhovsek, U. 2013. Early versus lateleaf removal strategies for Pinot noir (Vitis vinifera L.): effect on colour-related phenolics in young wines following alcoholic fermentation. Journal of the Science of Food and Agriculture 93: 3670-3681.

Lo Cicero, L.; Puglisi, I.; Nicolosi, E.; Gentile, A.; Ferlito, F.; Continella, A.; Lo Piero, A.R. 2016. Anthocyanin levels and expression analysis of biosynthesis related genes during ripening of sicilian and international grape berries subjected to leaf removal and water deficit. Journal of Agricultural Science of Technology 18: 1333-1344.

Lorenz, D.H.; Eichorn, H.; Bleiholder, H.; Klose, R.; Meier, U.; Weber, E. 1994. Phänologische Entwicklungsstadien der Weinrebe (Vitis vinifera (L.) ssp. vinifera) Codierung und Beschreiibung nach der erweiterten BBCH-Skala. (Phenological development stages of the grapevine (Vitis vinifera (L.) ssp. Vinifera) coding and description according to the extended BBCH scale). Viticulture Enology Science 49: 66-70.

Main, G.L.; Morris, J.R. 2004. Leaf-removal effects on Cynthiana yield, juice composition, and wine composition. American Journal of Enology and Viticulture 55: 147-152.

Matthews, M.A.; Anderson, M.M.; Schultz, H.R. 1987. Phenologic and growth responses to early and late season water deficits in Cabernet franc. Vitis 26: 147-160.

Nicolosi, E.; Continella, A.; Gentile, A.; Cicala, A.; Ferlito, F. 2012. Influence of early leaf removal on autochthonous and international grapevines in Sicily. Scientia Horticulturae 146: $1-6$.
Olivo, N.; Girona, J.; Marsal, J. 2009. Seasonal sensitivity of stem water potential to vapour pressure deficit in grapevine. Irrigation Science 27: 175-182.

Pastore, C.; Allegro, G.; Valentini, G.; Muzzi, E.; Filippetti, I. 2017. Anthocyanin and flavonol composition response to veraison leaf removal on Cabernet Sauvignon, Nero d'Avola, Raboso Piave and Sangiovese Vitis vinifera (L.) cultivars. Scientia Horticulturae 218: 147-155.

Petrie, P.R.; Clingeleffer, P.R. 2006. Crop thinning (hand versus mechanical), grape maturity and anthocyanins concentration: outcomes from irrigated Cabernet Sauvignon (Vitis vinifera L.) in a warm climate. Australian Journal of Grape and Wine Research 12: 21-29.

Pisciotta, A.; Scafidi, P.; Di Lorenzo, R.; Barbagallo, M.G. 2013. Manual and mechanical leaf removal in the bunch zone (Vitis vinifera L. 'Nero d'Avola'): effects on plant physiology, vegetative parameters, yield and grape quality in a warm area. Acta Horticulturae 978: 285-292.

Poni, S.; Bernizzoni, F.; Civardi, S. 2008. The effect of early leaf removal on whole canopy gas exchange and vine performance of Vitis vinifera L. 'Sangiovese'. Vitis 47: 1-6.

Poni, S.; Casalini, L.; Bernizzoni, F.; Civardi, S.; Intrieri, C. 2006. Effects of early defoliation on shoot photosynthesis, yield components, and grape composition. American Journal of Enology and Viticulture 57: 397-407.

Reynolds, A.G.; Wardle, D.A. 1989. Effects of timing and severity of summer hedging on growth, yield, fruit composition, and canopy characteristics of de Chaunac. 1. Canopy characteristics and growth parameters. American Journal of Enology and Viticulture 40: 109-120.

Scafidi, P.; Barbagallo, M.G.; Pisciotta, A.; Mazza, M.; Downey, M.O. 2018. Defoliation of two-wire vertical trellis: effect on grape quality. New Zealand Journal of Crop and Horticultural Science 46: 18-38.

Singleton, V.L.; Orthofer, R.; Lamuela-Raventos, R.M. 1999. Analysis of total phenols and other oxidation substrates and antioxidant by means of Folin-Ciocalteu reagent. Methods in Enzymology 299: 152-178.

Spayd, S.E.; Tarara, J.M.; Mee, D.L.; Ferguson, J.C. 2002. Separation of sunlight and temperature effects on the composition of Vitis vinifera cv. Merlot berries. American Journal of Enology and Viticulture 53: 171-181.

Tarara, J.M.; Lee, J.; Spayd, S.E.; Scagel, C.F. 2008. Berry temperature and solar radiation alter acylation, proportion, and concentration of anthocyanin in Merlot grapes. American Journal of Enology and Viticulture 59: 235-247.

Teixeira, A.; Eiras-Dias, J.; Castellarin, S.D.; Geros, H. 2013. Berry phenolics of grapevine under challenging environments. International Journal of Molecular Sciences 14: 18711-18739.

Triolo, R.; Roby, J.P.; Plaia, A.; Hilbert, G.; Buscemi, S.; Di Lorenzo, R.; Van Leeuwen, C. 2018. Hierarchy of factors impacting grape berry mass: separation of direct and indirect effects on major berry metabolites. American Journal of Enology and Viticulture 69: 103-112. 